\title{
Article \\ Effect of Mineral and Organic Fertilization on desi and kabuli Chickpea (Cicer arietinum L.): Plant Growth and Production, Hydration Properties, Bioactive Compounds, and Antioxidant Activity
}

\author{
Antonella Pasqualone $^{1}$ (D), Carmine Summo ${ }^{1}$ (D), Davide De Angelis ${ }^{1}$ (D), Giovanna Cucci ${ }^{2, *}$, Davide Caranfa ${ }^{2}$ \\ and Giovanni Lacolla ${ }^{2}$ \\ 1 Department of Soil, Plant, and Food Science (Di.S.S.P.A.), University of Bari 'Aldo Moro', Via Amendola, \\ 165/A, I-70126 Bari, Italy; antonella.pasqualone@uniba.it (A.P.); carmine.summo@uniba.it (C.S.); \\ davide.deangelis@uniba.it (D.D.A.) \\ 2 Department of Agricultural and Environmental Science (Di.S.A.A.T.), University of Bari 'Aldo Moro', \\ Via Amendola, 165/A, I-70126 Bari, Italy; davide.caranfa@gmail.com (D.C.); giovanni.lacolla@uniba.it (G.L.) \\ * Correspondence: giovanna.cucci@uniba.it
}

check for updates

Citation: Pasqualone, A.; Summo, C.; De Angelis, D.; Cucci, G.; Caranfa, D.; Lacolla, G. Effect of Mineral and Organic Fertilization on desi and kabuli Chickpea (Cicer arietinum L.): Plant Growth and Production, Hydration Properties, Bioactive Compounds, and Antioxidant Activity. Plants 2021, 10, 1441. https://doi.org/10.3390/ plants10071441

Academic Editor: Beatriz Ramos Solano

Received: 14 June 2021

Accepted: 12 July 2021

Published: 14 July 2021

Publisher's Note: MDPI stays neutral with regard to jurisdictional claims in published maps and institutional affiliations.

Copyright: (c) 2021 by the authors. Licensee MDPI, Basel, Switzerland. This article is an open access article distributed under the terms and conditions of the Creative Commons Attribution (CC BY) license (https:/ / creativecommons.org/licenses/by/ $4.0 /)$.

\begin{abstract}
Composting is a strategic technology to convert organic waste into environmentally friendly soil improvers, mitigating the pressure on landfills and contributing to sustainability. This research evaluates the effects of different doses of mineral/organic fertilizers on two chickpea types: desi and kabuli. A randomized block design with three replications and six conditions was adopted: non-fertilized control, two mineral fertilizations (M1, M2), and three organic fertilizations (B1, B2, B3). M1 and B1 provided for comparable NPK amounts. Fertilization and variety significantly influenced plant growth and production, and seed hydration. Fertilization had a lower influence on bioactive compounds. The highest seed yields were obtained with $\mathrm{M} 2$ (30-40-100 $\mathrm{kg} \mathrm{ha}^{-1}$ of N, $\mathrm{P}_{2} \mathrm{O}_{5}$, and $\mathrm{K}_{2} \mathrm{O}$, respectively. An addition of $40 \mathrm{~kg} \mathrm{ha}^{-1}$ of $\mathrm{P}_{2} \mathrm{O}_{5}$ (M1) had no effect on seed yield. B1 (10 $\mathrm{Mg} \mathrm{ha}^{-1}$ of Bio Vegetal) and M1 led to the same yield, which did not increase using higher doses of green compost. Mineral and organic fertilizations favored hydration and swelling of chickpeas. Desi chickpea showed a significantly higher seed yield but a lower seed weight than kabuli. Organic fertilization, combined with the recovery of peculiar chickpeas, which are more productive and richer in bioactive compounds, promotes a more sustainable food system.
\end{abstract}

Keywords: pigmented chickpea; vegetal compost; 100 seed weight; hydration capacity; phenolic compounds; anthocyanins

\section{Introduction}

Chickpea (Cicer arietinum L.) is a widely cultivated legume, with a world production of around 14.3 million tons in 2019 [1]. According to their physic-chemical and genetic characteristics, chickpeas include two main categories: kabuli, a chickpea type having large beige seeds, and desi, with smaller and rough brown to black seeds [2]. Furthermore, in Apulia (Southern Italy), a subtype of black-colored chickpea with its own genetic features [3] is traditionally cultivated, but modern beige cultivars with a softer and easier to cook coat are progressively replacing it, causing a decrease in genetic diversity [4]. Recent studies, however, evidenced that the Apulian black subtype has an interesting potential for the development of food products, such as purée [5], or in mixture with wheat flour or semolina, various baked goods [6], and pasta [7]. Chickpeas are also the basis for the preparation of various traditional foods in the Mediterranean area and Middle East, such as hummus, as well as in India, where chickpea-based foods like boondi, dhokla, pakora, and bhujia are very popular [8], not to mention the numerous foods currently available on the market for vegetarian and vegan consumers. 
Dietary habits are known to be closely linked to the onset of lifestyle-related pathologies. In this regard, the consumption of chickpeas leads to several health benefits, such as blood pressure regulation [9], decrease of postprandial glucose [10], and, in turn, prevention of diabetes mellitus and metabolic syndrome [11]. Chickpeas, indeed, have a good nutritional value, providing proteins, unsaturated fatty acids, dietary fiber, vitamins, and minerals $[12,13]$. Chickpeas also show significant antioxidant activity, related to the presence of bioactive compounds [13]. Interestingly, chickpea accessions with different contents of macronutrients and bioactive compounds showed a different ability to reduce the lipid over-accumulation in steatotic $\mathrm{FaO}$ hepatic cells and in mice liver [14]. In particular, black and brown desi type chickpeas showed a significantly higher content of anthocyanins and minerals (specifically $\mathrm{Mn}, \mathrm{Mg}$, and $\mathrm{Ca}$ ), which were positively correlated with the antioxidant activity assessed with the DPPH assay [15].

Over than the genetic factors related to the chickpea variety, other factors could influence the composition of chickpeas, such as environmental and agronomic conditions. It is therefore important to also understand the effect of fertilization on the content of bioactive compounds and antioxidant activity of chickpea seeds. Several studies have been carried out to assess the influence of agronomic factors, mostly fertilization type and dose, on plant growth, physiological traits, and seed yield [16-23]. Other studies have considered the effect of mineral, organic, and biological fertilization on the chemical composition and physical characteristics of chickpea seeds [24,25]. However, no studies are available in the literature on the effect of fertilization on the content of bioactive compounds and the level of antioxidant activity of chickpeas.

To meet the needs of circular economy, composting is considered a strategic technology to convert organic waste into environmentally friendly soil improvers, mitigating the pressure on landfills and reducing the incineration of industrial and urban organic waste [26,27]. Composted organic amendments, obtained from a wide range of plant sources, are now considered effective means for increasing soil organic matter and restoring fertility [28]. Moreover, the demand for organic products is progressively increasing and the rules for organic productions impose the use of organic fertilizers with the exclusion of any synthetic product.

To contribute to a more sustainable agriculture and to the recycling of biomass of vegetable origin, the aim of this research was to evaluate the effects of different doses of mineral/organic fertilization on plant growth and production, hydration properties, bioactive compounds, and antioxidant activity of desi and kabuli chickpeas.

\section{Results}

Table 1 reports the effect of different doses of organic or mineral fertilization on plant height and yield parameters of chickpea. A significant effect of both fertilization treatment and chickpea variety on plant height, shoot dry biomass, seed yield (always $p<0.001$ ), and 100 seed weight $(p=0.016)$ was observed. The effect of the treatment ${ }^{*}$ variety interaction was not significant. Plant height of both types of chickpeas (desi, cv. Senise, and kabuli, cv. Sultano) increased significantly in the fertilized trials compared to the unfertilized control. The average increase accounted for $8 \%$ with mineral fertilization and $11 \%$ with organic fertilization (Bio Vegetal green compost). Desi chickpeas showed higher plant height than kabuli. However, no statistical difference was found after comparing different doses of organic fertilization among them. Additionally, with mineral fertilization, an increase in the dose of phosphorous did not result in a significant variation of plant height. The shoot dry biomass increased significantly in the fertilized trials compared to the unfertilized control. The variety of chickpea showed a significant effect, with the biomass of desi being higher than kabuli. The interaction between the treatment and the variety was not significant; therefore, the chickpea varieties under investigation responded in the same way to the fertilization. The mineral fertilization induced a significantly higher amount of shoot dry biomass than the organic one. No statistically significant differences between different doses of mineral or organic fertilization were observed for shoot dry biomass. 
Table 1. Effect of different doses of mineral and organic fertilization on plant height and yield parameters of desi (cv. Senise) and kabuli (cv. Sultano) chickpeas (mean \pm standard deviations).

\begin{tabular}{|c|c|c|c|c|}
\hline \multirow{2}{*}{ Fertilization Type } & Plant Height & Shoot Dry Biomass & Seed Yield & 100 Seed Weight \\
\hline & $(\mathrm{cm})$ & $\left(\mathrm{Mg} \mathrm{ha}^{-1}\right)$ & $\left(\mathrm{Mg} \mathrm{ha}^{-1}\right)$ & g \\
\hline \multicolumn{5}{|l|}{ Desi (cv. Senise) } \\
\hline Co & $72.67 \pm 2.23^{\text {cdef }}$ & $3.01 \pm 0.16^{\mathrm{e}}$ & $1.22 \pm 0.15$ bcde & $24.15 \pm 0.52^{\mathrm{c}}$ \\
\hline M1 & $79.34 \pm 2.12^{\mathrm{abcd}}$ & $3.75 \pm 0.26^{\mathrm{a}}$ & $1.38 \pm 0.21^{\mathrm{ab}}$ & $25.28 \pm 0.23^{c}$ \\
\hline M2 & $77.00 \pm 3.25$ abcde & $3.68 \pm 0.21^{\mathrm{ab}}$ & $1.39 \pm 0.19^{a}$ & $24.50 \pm 0.31^{\mathrm{c}}$ \\
\hline B1 & $83.00 \pm 5.70^{a}$ & $3.16 \pm 0.34^{\text {cde }}$ & $1.30 \pm 0.22 \mathrm{abcd}$ & $24.47 \pm 0.22^{c}$ \\
\hline B2 & $82.00 \pm 3.86^{a b c}$ & $3.29 \pm 0.28^{\text {cde }}$ & $1.32 \pm 0.18^{\mathrm{abc}}$ & $24.58 \pm 0.21^{\mathrm{c}}$ \\
\hline B3 & $82.33 \pm 2.39 \mathrm{ab}$ & $3.35 \pm 0.49$ bcde & $1.35 \pm 0.34 \mathrm{abc}$ & $24.85 \pm 0.28^{c}$ \\
\hline \multicolumn{5}{|l|}{ Kabuli (cv. Sultano) } \\
\hline Co & $64.34 \pm 1.29^{f}$ & $2.64 \pm 0.28^{f}$ & $0.97 \pm 0.12^{\mathrm{f}}$ & $28.41 \pm 0.18^{b}$ \\
\hline M1 & $72.00 \pm 3.21$ def & $3.39 \pm 0.21 \mathrm{abcd}$ & $1.27 \pm 0.22$ abcde & $31.14 \pm 0.57^{\mathrm{ab}}$ \\
\hline M2 & $67.00 \pm 1.45^{\mathrm{f}}$ & $3.49 \pm 0.34^{\mathrm{abc}}$ & $1.25 \pm 0.32$ cde & $32.04 \pm 0.62^{\mathrm{a}}$ \\
\hline B1 & $68.00 \pm 2.24$ ef & $3.11 \pm 0.29 \mathrm{de}$ & $1.09 \pm 0.11$ ef & $32.51 \pm 0.74^{\mathrm{a}}$ \\
\hline B2 & $68.34 \pm 2.39$ ef & $3.20 \pm 0.32$ cde & $1.11 \pm 0.14^{\mathrm{de}}$ & $31.37 \pm 0.42^{\mathrm{ab}}$ \\
\hline B3 & $73.00 \pm 2.40$ bcdef & $3.01 \pm 0.25^{\mathrm{e}}$ & $1.12 \pm 0.16^{\mathrm{de}}$ & $31.19 \pm 0.29 \mathrm{ab}$ \\
\hline$p$-value $T^{*} V$ & 0.285 & 0.115 & 0.721 & 0.066 \\
\hline Desi & $79.39 \pm 4.78^{\mathrm{a}}$ & $3.37 \pm 0.29^{a}$ & $1.33 \pm 0.06^{\mathrm{a}}$ & $24.65 \pm 0.47^{b}$ \\
\hline Kabuli & $68.83 \pm 3.81^{b}$ & $3.14 \pm 0.31^{b}$ & $1.13 \pm 0.11^{b}$ & $31.11 \pm 1.81^{a}$ \\
\hline$p$-value $V$ & $<0.001$ & $<0.001$ & $<0.001$ & $<0.001$ \\
\hline Co & $68.50 \pm 4.68^{c}$ & $2.82 \pm 0.21^{c}$ & $1.09 \pm 0.15^{c}$ & $26.28 \pm 2.34^{b}$ \\
\hline M1 & $75.67 \pm 4.76^{\mathrm{ab}}$ & $3.57 \pm 0.23^{\mathrm{a}}$ & $1.31 \pm 0.09^{\mathrm{a}}$ & $28.21 \pm 3.30^{\mathrm{a}}$ \\
\hline M2 & $72.00 \pm 5.76^{b c}$ & $3.59 \pm 0.16^{\mathrm{a}}$ & $1.29 \pm 0.12^{\mathrm{ab}}$ & $28.29 \pm 4.22^{\mathrm{a}}$ \\
\hline B1 & $75.5 \pm 9.14^{a b}$ & $3.13 \pm 0.05^{b}$ & $1.19 \pm 0.12^{b}$ & $28.49 \pm 4.46^{\mathrm{a}}$ \\
\hline B2 & $75.33 \pm 7.50^{a b}$ & $3.25 \pm 0.17^{b}$ & $1.24 \pm 0.11^{\mathrm{ab}}$ & $27.97 \pm 3.94^{a b}$ \\
\hline B3 & $77.67 \pm 6.68^{a}$ & $3.18 \pm 0.22^{b}$ & $1.24 \pm 0.12^{a b}$ & $28.02 \pm 3.69 \mathrm{ab}$ \\
\hline$p$-value $T$ & 0.001 & $<0.001$ & $<0.001$ & 0.016 \\
\hline
\end{tabular}

$\mathrm{Co}=$ unfertilized control, $\mathrm{M}=$ mineral fertilization, $\mathrm{B}=$ organic fertilization with Bio Vegetal green compost (Tersan Puglia, Modugno, Italy). Doses of fertilizers are reported in Table 2. Different letters in columns indicate significant differences according to the Tukey's test at $\alpha=0.05$.

Table 2. Fertilization conditions applied to desi (cv Senise) and kabuli (cv Sultano) chickpeas.

\begin{tabular}{|c|c|c|c|c|}
\hline Treatment & Biovegetal (Mg ha $\left.{ }^{-1}\right)$ & $\mathrm{N}\left(\mathrm{kg} \mathrm{ha}^{-1}\right)$ & $\mathrm{P}_{2} \mathrm{O}_{5}\left(\mathrm{~kg} \mathrm{ha}^{-1}\right)$ & $\mathrm{K}_{2} \mathrm{O}\left(\mathrm{kg} \mathrm{ha}^{-1}\right)$ \\
\hline Co & 0 & 0 & 0 & 0 \\
\hline M1 & 0 & 30 (urea) & 80 (simple superphosphate) & 100 (potassium sulfate) \\
\hline M2 & 0 & 30 (urea) & 40 (simple superphosphate) & 100 (potassium sulfate) \\
\hline B1 & 10 & 160.0 & 68.8 & 112.0 \\
\hline B2 & 15 & 240.0 & 109.0 & 168.0 \\
\hline B3 & 20 & 320.0 & 137.6 & 224.0 \\
\hline
\end{tabular}

$\mathrm{Co}=$ unfertilized control; $\mathrm{M}$ = mineral fertilization; $\mathrm{B}$ = organic fertilization with Bio Vegetal green compost (Tersan Puglia, Modugno, Italy).

The seed yield increased significantly in the trials submitted to mineral and organic fertilization compared to the unfertilized control. The interaction between the two variables was not significant, suggesting that the fertilization affected the yield regardless of the variety of the chickpea. By comparing the organic fertilization at the lowest dose (B1, i.e., $10 \mathrm{Mg} \mathrm{ha}^{-1}$ of Bio Vegetal) with the mineral fertilization M1, which provided approximately the same NPK amount, a higher seed yield was observed in the latter. Such a difference with M1 was reduced by increasing the dose of Bio Vegetal compost. As already observed for plant height and shoot dry biomass, for seed yield, no statistically significant differences between different doses of mineral or organic fertilization were found.

Considering the "treatment" variable, significantly higher 100 seed weight was observed only for M1, M2, and B1 compared to the unfertilized control, whereas no significant differences were observed between different doses of mineral or organic fertilization. 
Regarding the effect of chickpea variety on plant growth and yield parameters, desi chickpea showed a significantly greater plant height and shoot dry biomass than kabuli. Seed yield was also higher in desi than kabuli $\left(1.33 \mathrm{Mg} \mathrm{ha}^{-1}\right.$ and $1.13 \mathrm{Mg} \mathrm{ha}^{-1}$ on average for desi and kabuli, respectively), while the 100 seed weight was lower (24.65 g and $31.11 \mathrm{~g}$ on average for desi and kabuli, respectively).

The hydration and swelling properties of chickpea seeds (HC, HI, SC, and SI) were all significantly influenced $(p<0.001)$ by fertilization treatment and chickpea variety (Table 3). A significant effect of the treatment*variety interaction was observed only for SI $(p=0.012)$. HC, HI, SC, and SI increased significantly in the fertilized trials compared to the unfertilized control. No significant differences in $\mathrm{HC}$ and $\mathrm{HI}$ were observed between mineral and organic fertilization, at any of the doses considered, and both in desi and kabuli chickpeas. Regarding the effect of chickpea variety on the hydration properties, desi chickpeas showed a significantly lower ability to hydrate $\left(0.28 \mathrm{vs} .0 .34 \mathrm{~g} \mathrm{seed}^{-1}\right.$ for HC and 84.80 vs. 95.57 for $\mathrm{HI}$ in desi and kabuli, respectively) and swell ( 0.23 vs. $0.27 \mathrm{~mL} \mathrm{seed}^{-1}$ for SC and 92.33 vs. 98.22 for SI in desi and kabuli, respectively) than kabuli ones. For SI, a significant interaction between the variables was observed. In particular, in kabuli chickpeas, a decrease of SI occurred when the concentration of the organic fertilization increased (B3), while no variation was observed in the desi variety.

Table 3. The effect of different doses of mineral and organic fertilization on the hydration and swelling properties of desi (cv. Senise) and kabuli (cv. Sultano) chickpeas (mean \pm standard deviations).

\begin{tabular}{|c|c|c|c|c|}
\hline \multirow{2}{*}{ Fertilization Type } & Hydration Capacity & Hydration Index & Swelling Capacity & Swelling Index \\
\hline & $\left(\right.$ g seed $\left.^{-1}\right)$ & \multicolumn{3}{|c|}{$\left(\mathrm{mL}\right.$ seed $\left.{ }^{-1}\right)$} \\
\hline \multicolumn{5}{|l|}{ Desi (cv. Senise) } \\
\hline Co & $0.24 \pm 0.01^{\mathrm{d}}$ & $79.01 \pm 1.00^{\mathrm{d}}$ & $0.18 \pm 0.01^{\mathrm{f}}$ & $84.19 \pm 2.01^{\mathrm{f}}$ \\
\hline M1 & $0.29 \pm 0.02^{c}$ & $86.79 \pm 1.01 \mathrm{bc}$ & $0.24 \pm 0.02^{\mathrm{de}}$ & $95.21 \pm 1.95^{\text {cde }}$ \\
\hline M2 & $0.27 \pm 0.01^{\mathrm{cd}}$ & $85.88 \pm 1.32^{b c}$ & $0.25 \pm 0.01$ cde & $94.50 \pm 2.00 \mathrm{cde}$ \\
\hline B1 & $0.28 \pm 0.01^{\mathrm{cd}}$ & $86.61 \pm 2.10^{b c}$ & $0.26 \pm 0.02^{b c d}$ & $91.78 \pm 2.29 \mathrm{e}$ \\
\hline B2 & $0.29 \pm 0.02^{\mathrm{c}}$ & $85.93 \pm 0.73 b c$ & $0.24 \pm 0.01 \mathrm{de}$ & $94.52 \pm 0.20$ cde \\
\hline B3 & $0.30 \pm 0.01 \mathrm{bc}$ & $84.58 \pm 1.49^{c}$ & $0.23 \pm 0.01^{\mathrm{de}}$ & $93.81 \pm 0.65^{\text {de }}$ \\
\hline \multicolumn{5}{|l|}{ Kabuli (cv. Sultano) } \\
\hline Co & $0.27 \pm 0.01^{\mathrm{cd}}$ & $88.51 \pm 1.36^{b}$ & $0.21 \pm 0.02$ ef & $91.93 \pm 0.48^{\mathrm{e}}$ \\
\hline M1 & $0.34 \pm 0.02 \mathrm{ab}$ & $96.92 \pm 0.06^{\mathrm{a}}$ & $0.27 \pm 0.02 \mathrm{bcd}$ & $98.12 \pm 0.04 \mathrm{abc}$ \\
\hline M2 & $0.36 \pm 0.02^{\mathrm{a}}$ & $97.83 \pm 0.82^{a}$ & $0.29 \pm 0.02 \mathrm{abc}$ & $99.54 \pm 0.17 \mathrm{ab}$ \\
\hline B1 & $0.35 \pm 0.01^{\mathrm{a}}$ & $96.69 \pm 0.54^{\mathrm{a}}$ & $0.31 \pm 0.01^{\mathrm{a}}$ & $99.74 \pm 0.11^{\mathrm{ab}}$ \\
\hline B2 & $0.34 \pm 0.02^{a b}$ & $95.92 \pm 0.93^{\mathrm{a}}$ & $0.30 \pm 0.01^{\mathrm{ab}}$ & $102.22 \pm 2.35^{\mathrm{a}}$ \\
\hline B3 & $0.36 \pm 0.02^{\mathrm{a}}$ & $97.55 \pm 0.05^{\mathrm{a}}$ & $0.27 \pm 0.01 \mathrm{abcd}$ & $97.80 \pm 0.11 \mathrm{bcd}$ \\
\hline$p$-value $T^{*} V$ & 0.059 & 0.076 & 0.352 & 0.012 \\
\hline Desi & $0.28 \pm 0.02^{b}$ & $84.80 \pm 2.99^{b}$ & $0.23 \pm 0.03^{b}$ & $92.33 \pm 4.16^{\mathrm{b}}$ \\
\hline Kabuli & $0.34 \pm 0.03^{\mathrm{a}}$ & $95.57 \pm 3.38^{a}$ & $0.27 \pm 0.04^{a}$ & $98.22 \pm 3.35^{\mathrm{a}}$ \\
\hline$p$-value $V$ & $<0.001$ & $<0.001$ & $<0.001$ & $<0.001$ \\
\hline Co & $0.26 \pm 0.02^{b}$ & $83.76 \pm 5.31^{b}$ & $0.20 \pm 0.02^{\mathrm{c}}$ & $88.06 \pm 4.44^{\mathrm{c}}$ \\
\hline M1 & $0.32 \pm 0.03^{\mathrm{a}}$ & $91.85 \pm 5.59^{a}$ & $0.25 \pm 0.02^{b}$ & $96.66 \pm 2.02 \mathrm{ab}$ \\
\hline M2 & $0.32 \pm 0.05^{\mathrm{a}}$ & $91.85 \pm 6.62^{\mathrm{a}}$ & $0.27 \pm 0.03^{a b}$ & $97.02 \pm 3.04^{\mathrm{ab}}$ \\
\hline B1 & $0.32 \pm 0.04^{\mathrm{a}}$ & $91.65 \pm 5.69^{a}$ & $0.29 \pm 0.03^{a}$ & $95.76 \pm 4.59^{b}$ \\
\hline B2 & $0.32 \pm 0.03^{\mathrm{a}}$ & $90.92 \pm 5.52^{\mathrm{a}}$ & $0.27 \pm 0.03^{a b}$ & $98.37 \pm 4.48^{\mathrm{a}}$ \\
\hline B3 & $0.33 \pm 0.04^{\mathrm{a}}$ & $91.07 \pm 7.17^{\mathrm{a}}$ & $0.25 \pm 0.02^{b}$ & $95.80 \pm 2.22^{b}$ \\
\hline$p$-value $T$ & $<0.001$ & $<0.001$ & $<0.001$ & $<0.001$ \\
\hline
\end{tabular}

$\mathrm{Co}=$ unfertilized control, $\mathrm{M}=$ mineral fertilization, $\mathrm{B}=$ organic fertilization with Bio Vegetal green compost (Tersan Puglia, Modugno, Italy). Doses of fertilizers are reported in Table 2. Different letters in columns indicate significant differences according to the Tukey's test at $\alpha=0.05$.

Table 4 reports the effect of different doses of organic or mineral fertilization on the total phenolic compounds, total anthocyanin compounds, and antioxidant activity of chickpea seeds. A significant effect was exerted by the fertilization treatment on phenolic compounds $(p<0.001)$, but only in kabuli chickpeas. In detail, the phenolics of kabuli 
chickpeas tended to decrease with fertilization compared to the unfertilized control. No significant effect of fertilization was observed on the anthocyanin content $(p=0.064)$, with the only exception being the desi chickpeas submitted to M2 mineral fertilization, which contained significantly more anthocyanins than both the unfertilized chickpeas and those fertilized with Bio Vegetal at the B2 dose. No significant effect of the fertilization treatment was observed on the antioxidant activity of chickpeas $(p=0.063)$, irrespective of the variety.

Table 4. The effect of different doses of mineral and organic fertilization on the total phenolic compounds, total anthocyanin compounds, and antioxidant activity of desi (cv. Senise) and kabuli (cv. Sultano) chickpeas (mean \pm standard deviation).

\begin{tabular}{|c|c|c|c|}
\hline Sample & $\begin{array}{l}\text { Total Phenolic Compounds } \\
\text { (mg ferulic acid/g d.m.) }\end{array}$ & $\begin{array}{l}\text { Total Anthocyanins (mg } \\
\text { cyanidin 3-O-glucoside/kg d.m.) }\end{array}$ & $\begin{array}{l}\text { Antioxidant Activity ( } \mu \mathrm{mol} \\
\text { Trolox/g d.m.) }\end{array}$ \\
\hline \multicolumn{4}{|l|}{ Desi (cv. Senise) } \\
\hline Co & $1.33 \pm 0.05^{\mathrm{ab}}$ & $71.43 \pm 1.08^{b}$ & $1.23 \pm 0.04^{\mathrm{a}}$ \\
\hline M1 & $1.25 \pm 0.03 \mathrm{bc}$ & $76.02 \pm 8.24^{a b}$ & $1.13 \pm 0.01^{\mathrm{ab}}$ \\
\hline M2 & $1.30 \pm 0.09 \mathrm{abc}$ & $89.28 \pm 11.93^{\mathrm{a}}$ & $1.22 \pm 0.06^{\mathrm{a}}$ \\
\hline B1 & $1.32 \pm 0.03 \mathrm{abc}$ & $74.73 \pm 9.77^{a b}$ & $1.22 \pm 0.08^{a}$ \\
\hline B2 & $1.29 \pm 0.01^{\mathrm{abc}}$ & $70.87 \pm 0.42^{b}$ & $1.16 \pm 0.01^{\mathrm{ab}}$ \\
\hline B3 & $1.23 \pm 0.01 \mathrm{bc}$ & $78.79 \pm 1.30^{\mathrm{ab}}$ & $1.23 \pm 0.04^{\mathrm{a}}$ \\
\hline \multicolumn{4}{|l|}{ Kabuli (cv. Sultano) } \\
\hline Co & $1.38 \pm 0.01^{\mathrm{a}}$ & $12.21 \pm 1.41^{\mathrm{c}}$ & $1.10 \pm 0.00^{b}$ \\
\hline M1 & $1.12 \pm 0.00^{\mathrm{de}}$ & $12.74 \pm 1.51^{\mathrm{c}}$ & $1.08 \pm 0.06^{b}$ \\
\hline M2 & $1.31 \pm 0.02^{a b c}$ & $12.11 \pm 0.53^{c}$ & $1.13 \pm 0.03^{\mathrm{ab}}$ \\
\hline B1 & $1.22 \pm 0.01 \mathrm{~cd}$ & $12.57 \pm 0.10^{\mathrm{c}}$ & $1.12 \pm 0.01^{\mathrm{ab}}$ \\
\hline B2 & $1.32 \pm 0.04^{\mathrm{abc}}$ & $13.28 \pm 1.14^{\mathrm{c}}$ & $1.18 \pm 0.03^{a b}$ \\
\hline B3 & $1.07 \pm 0.02 \mathrm{e}$ & $12.75 \pm 1.38^{c}$ & $1.08 \pm 0.01^{b}$ \\
\hline$p$-value $T^{*} V$ & $<0.001$ & 0.040 & 0.016 \\
\hline Desi & $1.29 \pm 0.05^{\mathrm{a}}$ & $76.85 \pm 8.76^{\mathrm{a}}$ & $1.20 \pm 0.06^{\mathrm{a}}$ \\
\hline Kabuli & $1.24 \pm 0.12^{b}$ & $12.61 \pm 1.03^{b}$ & $1.11 \pm 0.04^{b}$ \\
\hline$p$-value $V$ & $<0.001$ & $<0.001$ & $<0.001$ \\
\hline Co & $1.36 \pm 0.04^{\mathrm{a}}$ & $41.82 \pm 32.46$ & $1.16 \pm 0.08$ \\
\hline M1 & $1.19 \pm 0.07^{\mathrm{c}}$ & $44.38 \pm 35.06$ & $1.11 \pm 0.05$ \\
\hline M2 & $1.30 \pm 0.06^{\mathrm{ab}}$ & $50.70 \pm 42.94$ & $1.17 \pm 0.07$ \\
\hline B1 & $1.27 \pm 0.06^{b}$ & $43.65 \pm 34.60$ & $1.17 \pm 0.07$ \\
\hline B2 & $1.31 \pm 0.03^{\mathrm{ab}}$ & $42.08 \pm 31.56$ & $1.17 \pm 0.02$ \\
\hline B3 & $1.15 \pm 0.09^{c}$ & $45.77 \pm 36.19$ & $1.16 \pm 0.08$ \\
\hline$p$-value $T$ & $<0.001$ & 0.064 & 0.063 \\
\hline
\end{tabular}

$\mathrm{Co}=$ unfertilized control, $\mathrm{M}=$ mineral fertilization, $\mathrm{B}=$ organic fertilization with Bio Vegetal green compost (Tersan Puglia, Modugno, Italy). Doses of fertilizers are reported in Table 2. Trolox $=( \pm)$-6-Hydroxy-2,5,7,8-tetramethylchromane-2-carboxylic acid; $\mathrm{T}=\mathrm{Treatment}$; $\mathrm{V}=$ Variety. Different letters in column indicate significant differences according to the Tukey's test at $\alpha=0.05$.

Instead, both variety and treatment * variety interaction influenced the phenolics, anthocyanins, and antioxidant activity. A higher level of significance was observed for variety $(p<0.001)$ than for treatment * variety in the case of anthocyanins and antioxidant activity ( $p=0.040$ and $p=0.016$, respectively). Desi chickpeas showed higher levels of phenolic compounds (1.29 mg ferulic acid/g d.m.) than kabuli chickpeas (1.24 mg ferulic $\mathrm{acid} / \mathrm{g}$ d.m.). The strongest effect of variety was observed on total anthocyanins, which ranged from 12.11 to $13.28 \mathrm{mg}$ cyanidin $3-O-g l u c o s i d e ~ / \mathrm{kg}$ d.m. in kabuli and from 70.87 to $89.28 \mathrm{mg}$ cyanidin $3-\mathrm{O}$-glucoside $/ \mathrm{kg} \mathrm{d}$.m. in desi chickpeas. The antioxidant activity ranged from 1.08 to $1.18 \mu \mathrm{mol}$ Trolox/g d.m. in kabuli and from 1.13 to $1.23 \mu \mathrm{mol}$ Trolox/g d.m. in desi chickpeas.

\section{Discussion}

Mineral nutrition is one of the most important factors affecting plant growth and productivity, and $\mathrm{N}$ is the major nutrient required by crops. Both chickpea varieties were positively influenced by mineral fertilization (Table 1). An adequate supply of $\mathrm{N}$ is needed to achieve high yield potential in chickpea. Excessive doses of nitrogen can reduce 
production, while modest doses administered at sowing have a starter function [19,22,29]. Chickpea is usually managed with low fertilizer input. In agreement with our findings, Walley et al. [22] found that in dryland, mineral fertilization (30 or $45 \mathrm{~kg} \mathrm{~N} \mathrm{ha}^{-1}$ and $40 \mathrm{~kg}$ $\mathrm{P}_{2} \mathrm{O}_{5} \mathrm{ha}^{-1}$ ) enhanced the shoot dry biomass of both desi (cv. Myles) and kabuli (cv. Sanford) chickpeas. However, the same authors also observed that the seed yield significantly increased only in desi, while in our trial, only kabuli was positively influenced. Although high doses of phosphorous positively influence the production of chickpea [16], in our trials, an increase from 40 to $80 \mathrm{~kg} \mathrm{ha}^{-1}$ of $\mathrm{P}_{2} \mathrm{O}_{5}$ did not lead to a significant increase in seed yield and 100 seed weight, in accordance with the findings of Bicer [30].

The organic fertilization induced an increase of the seed yield and 100 seed weight, but only in kabuli. Other authors reported positive effects on chickpea growth using different types of organic fertilizers (compost, vermicompost, farmyard manure), without specifying the chickpea type [16,31]. Compost can most likely improve plant growth through various mechanisms, including the reduction of nutritional constraints, improvement of soil water retention, and decreased incidence and impact of parasites [26].

Regarding the comparison between mineral and organic fertilization, we found no significant differences in plant height, seed yield, and 100 seed weight between M1 and B1 treatments, which provided approximately the same amount of nutrients. This absence of significant differences between the M1 mineral treatment and the B1 organic treatment is relevant to enhance the use of compost and to meet the needs of a circular economy. Our results can barely be compared with the existing literature due to differences in the specific doses or treatments. Seleiman and Abdelaal [25] compared mineral fertilization ( $35 \mathrm{~kg} \mathrm{Nha}^{-1}$ as urea, $55 \mathrm{~kg} \mathrm{P}_{2} \mathrm{O}_{5} \mathrm{ha}^{-1}$, and $55 \mathrm{~kg} \mathrm{~K}_{2} \mathrm{O} \mathrm{ha}^{-1}$ ) with an organic foliar treatment consisting of humic acid $2 \mathrm{~kg} \mathrm{ha}^{-1}$ and found no significant differences in plant height, seed yield, and 100 seed weight. Chala and Obsa [16] observed that the combination of $1.75 \mathrm{Mg} \mathrm{ha}{ }^{-1}$ of vermicompost with $50 \mathrm{~kg} \mathrm{ha}^{-1}$ of phosphorus fertilizer led to a higher yield than with mineral fertilizer alone.

The positive influence of fertilization, compared to the non-fertilized control, on the hydration and swelling capacities of chickpeas (Table 3) agreed with Abdalla et al. [24], who found that mineral fertilization induced an increase in the hydration coefficient, which further increased in trials treated with biofertilizers (including Rhizobium and mycorrhizal inoculants). The HC values of kabuli chickpeas observed in our study agreed with those assessed by Patané et al. [32] in a set of 10 kabuli varieties. In detail, these authors found mean values of $0.36 \mathrm{~g} \mathrm{seed}^{-1}$, very similar to our results $\left(\right.$ mean $\left.=0.34 \mathrm{~g} \mathrm{seed}^{-1}\right)$.

The hydration properties of chickpea seeds were determined by soaking them in water for $7 \mathrm{~h}$ at room temperature. By soaking, chickpeas undergo an increase in weight, linked to the hydration capacity, and an increase in volume (swelling capacity). The soaking step is important both for domestic preparation and for the industrial production of canned chickpeas. Soaking reduces the cooking time necessary to obtain the desired softness, improves the sensory quality, and decreases the content of anti-nutritional factors, which can limit the biological value of chickpeas [33].

Khan et al. [34] and Olika et al. [35] found higher hydration and swelling capacity in kabuli than in desi chickpeas, and also pointed out that high values of these properties are related to shorter cooking times. The lower ability to hydrate and swell observed in desi compared to kabuli chickpeas was probably due to the harder seed coat of desi chickpeas, characterized by a rigid and extensively thickened palisade layer [2]. In addition, desi chickpeas are usually smaller and contain a lower amount of starch, sensible to swelling, than kabuli chickpeas [13]. Positive correlations were observed, in fact, between 100 seed weight and all hydration and swelling properties, at a higher level of significance for hydration than for swelling indices. In detail, 100 seed weight was correlated with HC $(r=0.879 ; p<0.001), \mathrm{HI}(r=0.974 ; p<0.001), \mathrm{SC}(r=0.742 ; p<0.05)$, and SI $(r=0.766$; $p<0.05)$.

Regarding the bioactive compounds (Table 4), the slight but significant effect of fertilization treatment on phenolics, observed only in kabuli chickpeas, induced a decrease 
of the content of these antioxidant molecules. The phenolic compounds are localized mostly in the pericarp of the seed, whose weight increase might have "diluted" their amount. A similar effect was already observed in faba beans [36]. A negative, but not significant, correlation between total phenolic compounds and 100 seed weight was observed.

Phenolic compounds are antioxidants that have been already reported in chickpeas by numerous authors [37-39]. The values of total phenolic compounds assessed in our trials roughly agreed with the $0.18-1.18 \mathrm{mg}$ ferulic acid/g d.m. range observed in a collection of 57 accessions of kabuli and desi chickpeas [13]. Pigmented chickpea seeds, belonging to the desi type, are known to contain more total phenols than cream-colored and beige seeds of the kabuli type [40], in agreement with our results. The phenolic compounds identified in chickpeas have been reported to reduce chronic inflammatory responses [41,42].

Regarding anthocyanins, limited literature is available, but it is well established that the seeds of desi chickpea varieties contain more anthocyanins than kabuli [43]. The observed strong effect of chickpea variety on anthocyanins was therefore obvious, with anthocyanins being the red pigments responsible, at high doses, for the brown-to-black color of the seed coat typical of desi varieties [13]. The absence of a significant effect of fertilization on the anthocyanin content of kabuli chickpeas was also expected, due to a limited presence of these pigments in the kabuli type. A limited effect of fertilization was observed only in desi chickpea, where a more positive influence on anthocyanin content was induced by mineral than organic fertilization. No studies are reported in the literature on the effect of fertilization on the anthocyanin content of desi chickpeas, but a similar positive effect of fertilization has been reported in pigmented barley, where higher nitrogen levels induced an increase of anthocyanins in the culm and spike, and a decrease in the leaves [44]. The presence of anthocyanins in the leaves of desi chickpea, as well as in the basal part of the stem and in branches, has been reported as a consequence of stress induced by high temperatures $\left(>35^{\circ} \mathrm{C}\right)$ [45]. Being antioxidants, anthocyanins are part of the defense system of plants, and are known to mitigate abiotic and biotic stress [46]. Nutrient deficiencies, especially of phosphorus and nitrogen, have been reported to induce the accumulation of anthocyanins in the seedlings of many plant species, such as maize [47], cabbage, cauliflower, kohl rabi, radish, and canola [48].

The levels of anthocyanin compounds assessed in the trials were within the variation range (14.91-159.62 mg cyanidin 3-O-glucoside / kg d.m.) observed in a previous survey on a large collection of different chickpea genotypes [13]. Due to their antioxidant activity, anthocyanins have health-promoting properties with respect to cardiovascular disease, cancer, inflammation, and diabetes [49].

The observed values of antioxidant activity agreed with the ranges reported in the literature (1.16-3.39 $\mu \mathrm{mol}$ Trolox/g d.m.) [13]. The antioxidant activity mirrored the anthocyanin data. Therefore, pigmented chickpea seeds showed higher antioxidant activity, corroborating previous studies $[40,50]$. A positive and significant correlation $(r=0.769$; $p=0.003$ ) was found between the anthocyanins and antioxidant activity of chickpeas. Pigmented chickpeas could be a potentially functional food in consideration of their interesting antioxidant activity, able to prevent degenerative diseases associated with free radical damage.

\section{Materials and Methods}

\subsection{Plant Cultivation and Experimental Trials}

Chickpea (Cicer arietinum L.) cv. Sultano (kabuli type) and cv. Senise (desi type) were grown in 2019 at the experimental station of DISAAT Department of University of Bari 'Aldo Moro', sited in Bari, Italy, in a rotational crop system in alternation with durum wheat. The Senise cultivar belongs to the desi type and is characterized by a seed with a wrinkled surface that ends with a hook-shaped apex covered by a black integument, with creamy-colored cotyledons. This cultivar is usually cultivated in Puglia and Basilicata, Southern Italy. The Sultano cultivar belongs to the kabuli type, and is characterized by a larger smooth seed of regular shape with a light-colored integument. 
The cultivation was carried out in cylindrical pots $(0.72 \mathrm{~m}$ in diameter and $0.60 \mathrm{~m}$ high), filled with $293 \mathrm{~kg}$ of sandy-loam soil, whose main physic-chemical characteristics, determined according to Violante [51], are reported in Table 5.

Table 5. Particle size distribution, chemical properties, and hydrologic properties of the soil used in the trials.

\begin{tabular}{|c|c|}
\hline Parameter & Value \\
\hline \multicolumn{2}{|l|}{ Particle size distribution: } \\
\hline Total sand $(2>\varnothing>0.02 \mathrm{~mm})\left(\mathrm{g} \mathrm{kg}^{-1}\right)$ & 506 \\
\hline Silt $(\%)(0.02>\varnothing>0.002 \mathrm{~mm})\left(\mathrm{g} \mathrm{kg}^{-1}\right)$ & 260 \\
\hline Clay $(\%)(\varnothing<0.002 \mathrm{~mm})\left(\mathrm{g} \mathrm{kg}^{-1}\right)$ & 234 \\
\hline \multicolumn{2}{|l|}{ Chemical properties: } \\
\hline Total nitrogen (Kjeldahl method) $\left(\mathrm{g} \mathrm{kg}^{-1}\right)$ & 1.2 \\
\hline Available phosphorus (Olsen method) $\left(\mathrm{mg} \mathrm{kg}^{-1}\right)$ & 18.5 \\
\hline Exchangeable potassium $\left(\mathrm{BaCl}_{2}\right.$ method $\left(\mathrm{mg} \mathrm{kg}^{-1}\right)$ & 231 \\
\hline Organic matter (Walkley Black method) $\left(\mathrm{g} 100 \mathrm{~g}^{-1}\right)$ & 1.7 \\
\hline 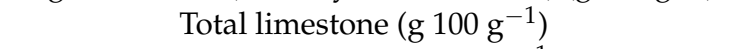 & 2.6 \\
\hline Active limestone $\left({\left.\mathrm{g} 100 \mathrm{~g}^{-1}\right)}\right.$ & 4.6 \\
\hline $\mathrm{pH}$ & 7.4 \\
\hline $\mathrm{ECe}\left(\mathrm{dS} \mathrm{m} \mathrm{m}^{-1}\right)$ & 0.5 \\
\hline ESP & 0.7 \\
\hline $\mathrm{CEC}\left(\mathrm{BaCl}_{2}\right.$ method) (meq $100 \mathrm{~g}^{-1}$ of soil d.m.) & 23.4 \\
\hline \multicolumn{2}{|l|}{ Hydrologic properties: } \\
\hline Field capacity ( $\mathrm{g} \mathrm{kg}^{-1}$ of soil d.m.) & 252 \\
\hline Wilting point $(-1.5 \mathrm{MPa})\left(\mathrm{g} \mathrm{kg}^{-1}\right.$ of soil d.m.) & 145 \\
\hline Bulk density $\left(\mathrm{t} \mathrm{m}^{-3}\right)$ & 13.6 \\
\hline
\end{tabular}

$\overline{\mathrm{ECe}}=$ saturation extract electrical conductivity; ESP = exchangeable sodium percentage; CEC = cation exchange capacity.

A randomized block experimental design with three replications was adopted and six conditions were compared: non-fertilized control (Co), two mineral fertilizations, and three organic fertilizations, as reported in Table 2. The mineral fertilization consisted of nitrogen and potassium in the doses of $30 \mathrm{~kg} \mathrm{ha}^{-1}$ of $\mathrm{N}$, applied as urea, and $100 \mathrm{~kg} \mathrm{ha}^{-1}$ of $\mathrm{K}_{2} \mathrm{O}$, which are the quantities usually distributed to the chickpea crop in Southern Italy, while the doses of phosphorus, applied as simple superphosphate, accounted for 80 and $40 \mathrm{~kg} \mathrm{ha}^{-1}$, indicated respectively with M1 and M2. Mineral fertilization was conducted at the time of sowing. The organic fertilization was based on the use of an organic fertilizer obtained from pruning residues of parks and gardens away from areas with high car traffic and wet organic municipal waste, all composted, namely the "Bio Vegetal" green compost (Tersan Puglia, Modugno, Italy).

The main physic-chemical characteristics of Bio Vegetal, determined according to the official methods of the current Italian legislation on organic fertilizers [52], are reported in Table 6. The green compost was used at the following doses: 10 (B1), 15 (B2), and 20 (B3) $\mathrm{Mg} \mathrm{ha}^{-1}$. The dose of $10 \mathrm{Mg} \mathrm{ha}^{-1}$ of Bio Vegetal corresponded approximately to the same quantities of $\mathrm{N}, \mathrm{P}_{2} \mathrm{O}_{5}$, and $\mathrm{K}_{2} \mathrm{O}$ provided by the highest dose of mineral fertilization (M1).

The compost was distributed in the $0-20 \mathrm{~cm}$ layer of soil, one month before sowing the chickpeas.

Sowing was carried out on 11 February 2019, at a density of 35 seeds $\mathrm{m}^{-2}$, which were distributed over 2 rows per pot. During the chickpea crop cycle, $410 \mathrm{~mm}$ of rain fell with a uniform distribution; therefore, no emergency irrigation interventions were necessary.

At the time of harvest, carried out when the grains were fully ripe on 21 July 2019, the following morpho-physiological parameters were measured: plant height and shoot dry biomass. Subsequently, on the dried chickpeas (12\% humidity), the seed yield and 100 seed weight were determined. 
Table 6. Physic-chemical properties of Bio Vegetal green compost (Tersan Puglia, Modugno, Italy). All values are expressed as dry matter.

\begin{tabular}{cc}
\hline Parameter & Value \\
\hline Moisture $\left({\left.\mathrm{g} 100 \mathrm{~g}^{-1}\right)}_{\mathrm{pH}}\right.$ & 20 \\
ECe $\left.(\mathrm{dS} \mathrm{m})^{-1}\right)$ & 7.5 \\
Total carbon $(\mathrm{C})\left(\mathrm{g} \mathrm{kg}^{-1}\right)$ & 1.57 \\
Total nitrogen $(\mathrm{N})\left(\mathrm{g} \mathrm{kg}^{-1}\right)$ & 300 \\
Organic nitrogen $\left({\left.\mathrm{g} 100 \mathrm{~g} \mathrm{~g}^{-1}\right)}_{\mathrm{C} / \mathrm{N}}\right.$ & 20 \\
Total phosphorus $(\mathrm{P})\left(\mathrm{g} \mathrm{kg}^{-1}\right)$ & 90 \\
Total potassium $(\mathrm{K})\left(\mathrm{g} \mathrm{kg}^{-1}\right)$ & 15 \\
Calcium $(\mathrm{Ca})\left(\mathrm{g} \mathrm{kg}^{-1}\right)$ & 8.6 \\
Magnesium $(\mathrm{Mg})\left(\mathrm{g} \mathrm{kg}^{-1}\right)$ & 14 \\
Zinc $\left.(\mathrm{Zn})(\mathrm{mg} \mathrm{kg})^{-1}\right)$ & 3.5 \\
Copper $(\mathrm{Cu})\left(\mathrm{mg} \mathrm{kg}^{-1}\right)$ & 1.2 \\
\hline
\end{tabular}

$\mathrm{ECe}=$ saturation extract electrical conductivity.

\subsection{Hydration Properties of Chickpea Seeds}

The hydration properties of chickpea seeds were assessed according to the method described in Patané et al. [32], with a slight modification related to the soaking temperature, which was $20^{\circ} \mathrm{C}$ instead of $30^{\circ} \mathrm{C}$. Water at room temperature was used to reproduce the usual domestic conditions adopted in the Mediterranean tradition for the preparation of legumes before cooking. First, the weight (Wi) of 50 chickpeas seeds was assessed. Then, the 50 chickpeas were transferred to a graduated cylinder and $100 \mathrm{~mL}$ of distilled water were added. Their initial volume (Vi) was determined, as (total volume $-100 \mathrm{~mL}$ ) $/ 50$ seeds. After $7 \mathrm{~h}$, the water was removed, the seeds were dried with absorbent paper, and weighed again (Wf). Then, the final volume of the hydrated chickpeas (Vf) was determined by placing them again in a graduated cylinder and adding $100 \mathrm{~mL}$ of distilled water. A 7-h period of immersion in water was chosen as it was observed that maximum absorption occurs during the first $7 \mathrm{~h}$ of soaking [53]. The hydration capacity (HC) $\left(\mathrm{g} \mathrm{seed}^{-1}\right)$, representing the weight of the absorbed water per seed, was calculated as (Wf $-\mathrm{Wi}) / 50$, while the hydration index (HI) was calculated as (Wf - Wi)/Wi. The swelling capacity (SC) $\left(\mathrm{mL}\right.$ seed $\left.{ }^{-1}\right)$, representing the increase in seed volume due to hydration, was calculated as $(\mathrm{Vf}-\mathrm{Vi}) / 50$, while the swelling index (SI) was calculated as $(\mathrm{Vf}-\mathrm{Vi}) / \mathrm{Vi}$. The analyses were carried out in triplicate.

\subsection{Chickpea Milling}

Dry chickpea seeds were milled to whole meal flour to determine the bioactive compounds and antioxidant activity. A laboratory mill equipped with a 1-mm sieve (Cyclotec Sample Mill, Tecator Foss, Hillerød, Denmark) was used.

\subsection{Moisture Content Determination}

The moisture content of whole meal flours was determined at $105^{\circ} \mathrm{C}$ by means of an automatic moisture analyzer (Radwag Wagi Elektroniczne, Radom, Poland). The analysis was carried out in triplicate.

\subsection{Determination of Total Phenolic Compounds}

The total phenolic compounds (TPCs) were extracted from $1 \mathrm{~g}$ of whole meal flour of dry chickpea seeds with $10 \mathrm{~mL}$ of an aqueous-methanol solution $(20: 80 \mathrm{v} / \mathrm{v})$. The suspension, put in centrifuge tubes, was stirred for $2 \mathrm{~h}$ in the dark, then centrifuged at $12,000 \times g$ for $3 \mathrm{~min}$ to recover the supernatant, which was subjected to Folin-Ciocalteu reaction in the conditions reported in Pasqualone et al. [54] and subsequent spectrophotometric measurement at $765 \mathrm{~nm}$ by a Cary $60 \mathrm{UV}-$ Vis spectrophotometer (Agilent Technologies, Santa Clara, CA, USA). The content of TPC was expressed as $\mathrm{mg} \mathrm{g}^{-1}$ of ferulic acid on 
dry matter (d.m.), considering a calibration curve previously prepared with ferulic acid (Merck KGaA, Darmstadt, Germany) at different concentrations. The analysis was carried out in triplicate.

\subsection{Determination of Total Anthocyanin Compounds}

The total anthocyanin compounds (TACs) were extracted from $1 \mathrm{~g}$ of whole meal flour of dry chickpea seeds with $10 \mathrm{~mL}$ of 85:15 $(v / v)$ methanol/1 $\mathrm{M} \mathrm{HCl}$. The suspension was stirred for $30 \mathrm{~min}$ in the dark, then centrifuged at $12,000 \times g$ for $5 \mathrm{~min}$ to recover the supernatant. The pellet was re-extracted with $10 \mathrm{~mL}$ of the solvent in the same conditions and, after centrifugation at $12,000 \times \mathrm{g}$ for $5 \mathrm{~min}$, the two supernatants were mixed and their absorbance was determined at $535 \mathrm{~nm}$ by a Cary $60 \mathrm{UV}-$ Vis spectrophotometer (Agilent Technologies, Santa Clara, CA, USA). Cyanidin 3-O-glucoside standard (Phytoplan, Heidelberg, Germany) was used to prepare the calibration curve in order to express total anthocyanins as $\mathrm{mg} \mathrm{kg}^{-1}$ of cyanidin 3-O-glucoside on dry matter. The analysis was carried out in triplicate.

\subsection{Determination of Antioxidant Activity}

The same aqueous-methanol extract prepared for the extraction of TPC was used for determining the antioxidant activity (AA) by the 2,2-diphenyl-1-picrylhydrazyl (DPPH) radical scavenging capacity assay as described in Pasqualone et al. [55]. AA was then expressed as $\mu \mathrm{mol}( \pm$ )-6-Hydroxy-2,5,7,8-tetramethylchromane-2-carboxylic acid (Trolox; Merck KGaA, Darmstadt, Germany) equivalent $\mathrm{g}^{-1}$ on dry matter. The analysis was carried out in triplicate.

\subsection{Statistical Analyses}

All data were submitted to two-way ANOVA, at a significance level $\alpha=0.05$, followed by Tukey's Honestly Significant Differences (HSD) test for post hoc multiple comparisons, in order to estimate the influence of each variable-fertilization treatment, chickpea variety-and of their first-order interaction, using Minitab 17 Statistical Software (Minitab, Inc., State College, PA, USA).

\section{Conclusions}

The obtained results highlight the significant effects of fertilization treatment and chickpea variety on plant growth and production, and the hydration properties of seeds. A lower influence of fertilization, instead, was observed on bioactive compounds, and no effect was assessed on the antioxidant activity.

The highest seed yields were obtained with mineral fertilization applied before sowing at the dose of $30-40-100 \mathrm{~kg} \mathrm{ha}^{-1}$ of $\mathrm{N}, \mathrm{P}_{2} \mathrm{O}_{5}$, and $\mathrm{K}_{2} \mathrm{O}$, respectively (M2). A further contribution of $40 \mathrm{~kg} \mathrm{ha}^{-1}$ of $\mathrm{P}_{2} \mathrm{O}_{5}$ (M1) did not result in an increase in seed yield. Good yields were also achieved with organic fertilization, at a dose of $10 \mathrm{Mg} \mathrm{ha}^{-1}$ (B1), of Bio Vegetal green compost distributed one month before sowing. This dose provided approximately the same NPK amount as the mineral fertilization M1. There was no increase in seed yield with the use of higher doses of green compost.

Both mineral and organic fertilization favored hydration and swelling in both types of chickpeas.

Desi chickpea, characterized by higher contents of bioactive compounds and antioxidant activity than kabuli, showed a significantly higher seed yield but lower 100 seed weight.

These results indicate that the organic fertilization with vegetal compost, combined with the recovery of pigmented varieties of chickpea, which are more productive and at the same time richer in bioactive compounds, are useful in creating more sustainable food systems suitable for modern dietary needs. 
Author Contributions: Conceptualization, G.C.; methodology, G.L.; formal analysis, G.L.; investigation, D.D.A., D.C.; data curation, A.P., C.S., D.C., G.L.; Statistical analysis: C.S., D.D.A., writingoriginal draft preparation, A.P., G.C.; writing-review and editing, A.P. All authors have read and agreed to the published version of the manuscript.

Funding: This research was funded by Agropolis Fondation, Fondazione Cariplo, and Daniel \& Nina Carasso Foundation through the "Investissements d'avenir" program with reference number ANR-10-LABX-0001-01, under the "Thought for Food" Initiative (project “LEGERETE").

Data Availability Statement: The data that support the findings of this study are available from the corresponding author, upon reasonable request.

Conflicts of Interest: The authors declare no conflict of interest.

\section{References}

1. Food and Agriculture Organization of the United Nations. Data of Crops Production (2019). 2019. Available online: http: //www.fao.org/faostat/en/\#data/QC (accessed on 11 June 2021).

2. Wood, J.A.; Knights, E.J.; Choct, M. Morphology of chickpea seeds (Cicer arietinum L.): Comparison of desi and kabuli types. Int. J. Plant Sci. 2011, 172, 632-643. [CrossRef]

3. Pavan, S.; Lotti, C.; Marcotrigiano, A.R.; Mazzeo, R.; Bardaro, N.; Bracuto, V.; Ricciardi, F.; Taranto, F.; D'Agostino, N.; Schiavulli, A.; et al. A Distinct Genetic Cluster in Cultivated Chickpea as Revealed by Genome-wide Marker Discovery and Genotyping. Plant Genome 2017, 10. [CrossRef]

4. De Giovanni, C.; Pavan, S.; Taranto, F.; Di Rienzo, V.; Miazzi, M.M.; Marcotrigiano, A.R.; Mangini, G.; Montemurro, C.; Ricciardi, L.; Lotti, C. Genetic variation of a global germplasm collection of chickpea (Cicer arietinum L.) including Italian accessions at risk of genetic erosion. Physiol. Mol. Biol. Plants 2021, 23, 197-205. [CrossRef] [PubMed]

5. Summo, C.; De Angelis, D.; Rochette, I.; Mouquet-Rivier, C.; Pasqualone, A. Influence of the preparation process on the chemical composition and nutritional value of canned purée of kabuli and Apulian black chickpeas. Heliyon 2019, 5, e01361. [CrossRef] [PubMed]

6. Pasqualone, A.; De Angelis, D.; Squeo, G.; Difonzo, G.; Caponio, F.; Summo, C. The Effect of the Addition of Apulian black Chickpea Flour on the Nutritional and Qualitative Properties of Durum Wheat-Based Bakery Products. Foods 2019, 8, 504. [CrossRef] [PubMed]

7. De Pasquale, I.; Verni, M.; Verardo, V.; Gómez-Caravaca, A.M.; Rizzello, C.G. Nutritional and Functional Advantages of the Use of Fermented Black Chickpea Flour for Semolina-Pasta Fortification. Foods 2021, 10, 182. [CrossRef]

8. Kaur, R.; Prasad, K. Technological, processing and nutritional aspects of chickpea (Cicer arietinum)-A review. Trends Food Sci. Technol. 2021, 109, 448-463. [CrossRef]

9. Bhagyawant, S.S.; Narvekar, D.T.; Gupta, N.; Bhadkaria, A.; Gautam, A.K.; Srivastava, N. Chickpea (Cicer arietinum L.) Lectin Exhibit Inhibition of ACE-I, $\alpha$-amylase and $\alpha$-glucosidase Activity. Protein Pept. Lett. 2019, 26, 494-501. [CrossRef]

10. Winham, D.M.; Hutchins, A.M.; Thompson, S.V. Glycemic response to black beans and chickpeas as part of a rice meal: A randomized cross-over trial. Nutrients 2017, 9, 1095. [CrossRef]

11. Aisa, H.A.; Gao, Y.; Yili, A.; Ma, Q.; Cheng, Z. Beneficial Role of Chickpea (Cicer arietinum L.) Functional Factors in the Intervention of Metabolic Syndrome and Diabetes Mellitus. In Bioactive Food as Dietary Interventions for Diabetes; Academic Press: Cambridge, MA, USA, 2019; pp. 615-662.

12. Jukanti, A.K.; Gaur, P.M.; Gowda, C.L.L.; Chibbar, R.N. Nutritional quality and health benefits of chickpea (Cicer arietinum L.): A review. Br. J. Nutr. 2012, 108, S11-S26. [CrossRef] [PubMed]

13. Summo, C.; De Angelis, D.; Ricciardi, L.; Caponio, F.; Lotti, C.; Pavan, S.; Pasqualone, A. Data on the chemical composition, bioactive compounds, fatty acid composition, physico-chemical and functional properties of a global chickpea collection. Data Brief 2019, 27, 104612. [CrossRef] [PubMed]

14. Centrone, M.; Gena, P.; Ranieri, M.; Di Mise, A.; D’agostino, M.; Mastrodonato, M.; Venneri, M.; De Angelis, D.; Pavan, S.; Pasqualone, A.; et al. In vitro and in vivo nutraceutical characterization of two chickpea accessions: Differential effects on hepatic lipid over-accumulation. Antioxidants 2020, 9, 268. [CrossRef] [PubMed]

15. Costantini, M.; Summo, C.; Centrone, M.; Rybicka, I.; D’agostino, M.; Annicchiarico, P.; Caponio, F.; Pavan, S.; Tamma, G.; Pasqualone, A. Macro-and Micro-Nutrient Composition and Antioxidant Activity of Chickpea and Pea Accessions. Pol. J. Food Nutr. Sci. 2021, 71, 2083-6007. [CrossRef]

16. Chala, G.; Obsa, Z. Effect of Organic and Inorganic Fertilizers on Growth, Yield and Yield Components of Chick Pea (Cicer arietinum) and Enhancing Soil Chemical Properties on Vertisols at Ginchi, Central Highlands of Ethiopia. J. Biol. Agric. Healthc. 2017, 7, 28-34.

17. McKenzie, B.A.; Hill, G.D. Growth and yield of two chickpea (Cicer arietinum L.) varieties in Canterbury, New Zealand. N. Z. J. Crop. Hortic. Sci. 1995, 23, 467-474. [CrossRef]

18. Namvar, A.; Sharifi, R.S. Phenological and morphological response of chickpea (Cicer arietinum L.) to symbiotic and mineral nitrogen fertilization. Žemdirbystè 2011, 98, 121-130. 
19. Namvar, A.; Sharifi, R.S.; Khandan, T. Growth analysis and yield of chickpea (Cicer arietinum L.) in relation to organic and inorganic nitrogen fertilization. Ekologija 2011, 57, 97-108. [CrossRef]

20. Namvar, A.; Sharifi, R.S.; Sedghi, M.; Zakaria, R.A.; Khandan, T.; Eskandarpour, B. Study on the effects of organic and inorganic nitrogen fertilizer on yield, yield components, and nodulation state of Chickpea (Cicer arietinum L.). Commun. Soil Sci. Plant Anal. 2011, 42, 1097-1109. [CrossRef]

21. Saleem, K.M.; Ali, K.A. Response of two Chickpea genotypes to different fertilizers composition and different application forms. Zanco J. Pure Appl. Sci. 2021, 33, 120-130. [CrossRef]

22. Walley, F.L.; Boahen, S.K.; Hnatowich, G.; Stevenson, C. Nitrogen and phosphorus fertility management for desi and kabuli chickpea. Can. J. Plant Sci. 2005, 85, 73-79. [CrossRef]

23. Namvar, A.; Sharifi, R.S.; Khandan, T.; Moghadam, M.J. Organic and Inorganic Nitrogen Fertilization Effects on Some Physiological and Agronomical Traits of Chickpea (Cicer arietinum L.) in Irrigated Condition. J. Cent. Eur. Agric. 2013, 14, 28-40. [CrossRef]

24. Abdalla, A.S.; Abdelgani, M.E.; Osman, A.G. Effects of biological and mineral fertilization on yield, chemical composition and physical characteristics of chickpea (Cicer arietinum L.) seeds. Pakistan J. Nutr. 2013, 12, 1-7. [CrossRef]

25. Seleiman, M.F.; Abdelaal, M.S. Effect of Organic, Inorganic and Bio-fertilization on Growth, Yield and Quality Traits of Some Chickpea (Cicer arietinum L.) Varieties. Egypt. J. Agron. 2018, 40, 105-117. [CrossRef]

26. Cucci, G.; Lacolla, G.; Mastro, M.A.; Caranfa, D.; Monteforte, A.; De Corato, U. Green compost influences yield and quality of carrots (Daucus carota L.) by enhancing root rot suppression to Sclerotinia sclerotiorum (Lib. de bary). Eur. J. Hortic. Sci. 2020, 85, 411-421. [CrossRef]

27. De Corato, U.; Salimbeni, R.; De Pretis, A.; Patruno, L.; Avella, N.; Lacolla, G.; Cucci, G. Microbiota from 'next-generation green compost' improves suppressiveness of composted Municipal-Solid-Waste to soil-borne plant pathogens. Biol. Control. 2018, 124, 1-17. [CrossRef]

28. Cucci, G.; Lacolla, G.; Caranfa, G. Use of composted olive waste as soil conditioner and its effects on the soil. Int. J. Agric. Res. 2013, 8, 149-157. [CrossRef]

29. López-Bellido, F.J.; López-Bellido, R.J.; Khalil, S.K.; López-Bellido, L. Effect of planting date on winter Kabuli chickpea growth and yield under rainfed Mediterranean conditions. Agron. J. 2008, 100, 957-964. [CrossRef]

30. Bicer, B.T. The effect of phosphorus doses on chickpea cultivars under rainfall conditions. Cercet. Agron. Mold. 2014, 47, 89-95. [CrossRef]

31. Korbu, L.; Tafes, B.; Kassa, G.; Mola, T.; Fikre, A. Unlocking the genetic potential of chickpea through improved crop management practices in Ethiopia. A review. Agron. Sustain. Dev. 2020, 40, 1-20. [CrossRef]

32. Patanè, C.; Iacoponi, E.; Raccuia, S.A. Physico-chemical characteristics, water absorption, soaking and cooking properties of some Sicilian populations of chickpea (Cicer arietinum L.). Int. J. Food Sci. Nutr. 2004, 55, 547-554. [CrossRef]

33. El-Hady, E.A.A.; Habiba, R.A. Effect of soaking and extrusion conditions on antinutrients and protein digestibility of legume seeds. LWT Food Sci. Technol. 2003, 36, 285-293. [CrossRef]

34. Khan, M.A.; Akhtar, N.; Ullah, I.; Jaffery, S. Nutritional evaluation of desi and kabuli chickpeas and their products commonly consumed in Pakistan. Int. J. Food Sci. Nutr. 1995, 46, 215-223. [CrossRef] [PubMed]

35. Olika, E.; Abera, S.; Fikre, A. Physicochemical properties and effect of processing methods on mineral composition and antinutritional factors of improved chickpea (Cicer arietinum L.) Varieties Grown in Ethiopia. Int. J. Food Sci. 2019, 2019. [CrossRef]

36. Cucci, G.; Lacolla, G.; Summo, C.; Pasqualone, A. Effect of organic and mineral fertilization on faba bean (Vicia faba L.). Sci. Hortic. 2019, 243, 338-343. [CrossRef]

37. Magalhães, S.C.Q.; Taveira, M.; Cabrita, A.R.J.; Fonseca, A.J.M.; Valentão, P.; Andrade, P.B. European marketable grain legume seeds: Further insight into phenolic compounds profiles. Food Chem. 2017, 215, 177-184. [CrossRef]

38. Singh, B.; Singh, J.P.; Kaur, A.; Singh, N. Phenolic composition and antioxidant potential of grain legume seeds: A review. Food Res. Int. 2017, 101, 1-16. [CrossRef]

39. Sreerama, Y.N.; Sashikala, V.B.; Pratape, V.M. Variability in the distribution of phenolic compounds in milled fractions of chickpea and horse gram: Evaluation of their antioxidant properties. J. Agric. Food Chem. 2010, 58, 8322-8330. [CrossRef]

40. Toğay, Y.; Toğay, N.; Çı̆̆ , F.; Akkoç, G. Determination of some quality criteria and nutrient contents of local black chickpea genotypes growth in different locations. Appl. Ecol. Environm. Res. 2019, 17, 10575-10585. [CrossRef]

41. Chino, X.M.S.; Martínez, C.J.; Garzón, V.R.V.; González, I.Á.; Treviño, S.V.; Bujaidar, E.M.; Ortiz, G.D.; Hoyos, R.B. Cooked Chickpea Consumption Inhibits Colon Carcinogenesis in Mice Induced with Azoxymethane and Dextran Sulfate Sodium. J. Am. Coll. Nutr. 2017, 36, 391-398. [CrossRef]

42. Monk, J.M.; Wu, W.; McGillis, L.H.; Wellings, H.R.; Hutchinson, A.L.; Liddle, D.M.; Graf, D.; Robinson, L.E.; Power, K.A. Chickpea supplementation prior to colitis onset reduces inflammation in dextran sodium sulfate-treated C57BL/6 male mice. Appl. Physiol. Nutr. Metab. 2018, 43, 893-901. [CrossRef] [PubMed]

43. Ghosh, A.; Dadhich, A.; Bhardwaj, P.; Babu, J.N.; Kumar, V. Comparative analysis of metabolites in contrasting chickpea cultivars. J. Plant Biochem. Biotechnol. 2020, 29, 253-265. [CrossRef]

44. Song, T.-H.; Han, O.-K.; Park, T.-I.; Kim, Y.-K.; Kim, K.-J.; Park, K.-H. Effect of Nitrogen Top Dressing Levels on Productivity, Feed Value, and Anthocyanin Content of Colored Barley. J. Korean Soc. Grassl. Forage Sci. 2012, 32, 149-156. [CrossRef] 
45. Bhasker, P.; Nandwal, A.S.; Kumar, N.; Chand, G.; Yadav, S.P.; Devi, S.; Singh, S. High Temperature Significance of Anthocyanins Accumulation Stress Responses in Chickpea (Cicer arietinum L.). Int. J. Agric. Innov. Res. 2018, 6, 2319-2473.

46. Ahmed, N.U.; Park, J.I.; Jung, H.J.; Hur, Y.; Nou, I.S. Anthocyanin biosynthesis for cold and freezing stress tolerance and desirable color in Brassica rapa. Funct. Integr. Genom. 2015, 15, 383-394. [CrossRef] [PubMed]

47. Cobbina, J.; Miller, M.H. Purpling in Maize Hybrids as Influenced by Temperature and Soil Phosphorus 1. Agron. J. 1987, 79, 576-582. [CrossRef]

48. Hodges, D.M.; Nozzolillo, C. Anthocyanin and Anthocyanoplast Content of Cruciferous Seedlings Subjected to Mineral Nutrient Deficiencies. J. Plant Physiol. 1996, 147, 749-754. [CrossRef]

49. Koh, K.; Youn, J.E.; Kim, H.S. Identification of anthocyanins in black soybean (Glycine max (L.) Merr.) varieties. J. Food Sci. Technol. 2014, 51, 377-381. [CrossRef]

50. Summo, C.; De Angelis, D.; Ricciardi, L.; Caponio, F.; Lotti, C.; Pavan, S.; Pasqualone, A. Nutritional, physico-chemical and functional characterization of a global chickpea collection. J. Food Compos. Anal. 2019, 84, 103306. [CrossRef]

51. Violante, P. Metodi di Analisi Chimica del Suolo-Violante, P.-Libri; Franco Angeli Editore: Milan, Italy, 2000. (In Italian)

52. ANPA-Agenzia Nazionale per la Protezione dell'Ambiente. Metodi di analisi del compost: Manuale e Linee Guida; ANPA: Rome, Italy, 2001; p. 130. (In Italian)

53. Wood, J.A.; Harden, S. A method to estimate the hydration and swelling properties of chickpeas (Cicer arietinum L.). J. Food Sci. 2006, 71, E190-E195. [CrossRef]

54. Pasqualone, A.; Delvecchio, L.N.; Mangini, G.; Taranto, F.; Blanco, A. Variability of total soluble phenolic compounds and antioxidant activity in a collection of tetraploid wheat. Agric. Food Sci. 2014, 23, 307-316. [CrossRef]

55. Pasqualone, A.; Makhlouf, F.Z.; Barkat, M.; Difonzo, G.; Summo, C.; Squeo, G.; Caponio, F. Effect of acorn flour on the physico-chemical and sensory properties of biscuits. Heliyon 2019, 5, e2242. [CrossRef] [PubMed] 